\title{
Valorization of natural clay as an ecological catalyst in the regioselective synthesis of some heterocyclic compounds based on 1,2,3-triazoles
}

\author{
W. Chalouati ${ }^{1}$, F. Ammari ${ }^{2}$, R. Hayder ${ }^{3}$, N. Besbes ${ }^{3}$, C. Girard ${ }^{\text {d }}$, A. Ouerghui ${ }^{* 1}$ \\ ${ }^{1}$ Laboratory of Functional Physiology and Valuation of Bio-resources (UR17ES27), Higher Institute of Biotechnology \\ of Béja, B.P. 382-9000 Béja, University of Jendouba, Tunisia. \\ ${ }^{2}$ Laboratory of Organic Synthesis (Unit: 05/UR/12-05), Carthage University, Faculty of Sciences of Bizerte, 7021 \\ Jarzouna, Bizerte, Tunisia \\ ${ }^{3}$ Group of Green and Applied Organic Chemistry, Laboratory of Composite Materials and Clay Minerals, National \\ Center for Research in Materials Science, Technopole of Borj Cedria, 8027, Soliman, Tunisia. \\ ${ }^{4}$ Institute of Chemistry for Life and Health Sciences, SEISAD group, UMR 8060 CNRS, Chimie Paristech - PSL \\ University, 11 rue Pierre et Marie Curie, 75005 Paris, France \\ * Corresponding author e-mail: ouerghiabid@gmail.com
}

\section{Abstract}

Some ecological catalysts were prepared from Tunisian clays; they have been applied in the catalytic coupling reaction of alkynes and azides to prepare bioactive heterocyclic compounds based on 1,2,3-triazoles. Clays used in this work were taken from Jebal Shib (M'dhilla) and Jebal Es Sath (between Gafsa and Metlaoui) in Gafsa at South West of Tunisia. The reaction of terminal alkynes with azides in the presence of studied catalysts was studied for 36 hours at room temperature without solvents and excitements; two isomers $(1,4)$ and $(1,5)$ of 1,2,3-triazoles were obtained. Generally, the $(1,4)$ isomer was obtained with an important proportion if $\mathrm{Cu}$-Pullard clay was used as a catalyst in this synthesis reaction. The studied ecological catalysts were characterized by X-ray diffraction and IR spectroscopy. Heterocyclic triazoles were analyzed by ${ }^{1} \mathrm{HNMR},{ }^{13} \mathrm{CNMR}$, Infrared (IR), and Ultraviolet spectroscopy. LC-MS analyses evaluated the molecular masses of synthesized triazoles.

Keywords: Tunisian clays, Catalysts, Regioselective Synthesis, 1,2,3-triazole. 1,4 isomer, 1,5 isomer

\section{INTRODUCTION}

Nowadays, the chemistry of heterocyclic compounds is considerably developing for their biological activities [1,2]. The most applied heterocycles in the field of biology are dioxolanes and triazoles. Dioxolanes are heterocyclic acetal compounds with a cycle containing five atoms; two are oxygen. Several types of research report the synthesis of dioxolanes using activated clays as catalysts [3-8]. In contrast, triazoles are heterocyclic compounds with three nitrogen atoms placed in 1,2,3 or 1,2,4 positions of the cycle. This report presents the triazoles compounds with a cycle containing five atoms; three are nitrogen, placed in the 1,2,3 position of the cycle. These triazoles compounds have a several biological activities: Antiproliferative [9], anti-inflammatory [10], antitubercular [11], tyrosinase inhibitory [12], antioxidant [13, 14] and antibacterial [15]. For this reason, the synthesis of triazoles was considerably developed. Several methods are applied in the synthesis of triazoles. The catalysts used in these syntheses are also diverse. Some syntheses of triazoles were carried out with green catalysts prepared from modified clays [16-18], other studies used catalysts prepared from copper (I) fixed on the organic polymers [19-21], CuI-catalyst for organic solvents, and CuI-catalysts for aqueous conditions are developed [18]. Stålsmeden et al. [21] synthesized 1,4 and 1,5-disubstituted-triazoles via $\mathrm{Cu}$ and Ru-catalyzed click reactions. Kumar and co-workers reported the synthesis of triazoles using copper-catalyzed azidealkyne (CuAAC) and Ru-catalyzed azide-alkyne cycloaddition (RuAAC) [22]. Application in the regioselective synthesis of 1,2,3-triazoles using CuI nanoparticles on 3-aminopyridine modified poly(styrene-c-maleic anhydride) as catalyst was reported by Hossiennejad et al. [23]. Khaled et al. [24] applied the copper oxide chitosan nanocomposite for the green regioselective synthesis of 1,2,3-triazoles. In this present work, we applied some modified Tunisian clays as catalysts for testing them in the synthesis of 1,2,3-triazoles with biological activities.

\section{EXPERIMENTAL}

\subsection{Materials}

Copper (I) iodide ( $\geq 99.5 \%$ ), methyl propionate (99\%), 1,4-benzodioxane-6- amine ( $\geq 98 \%)$, aniline ( $\geq 99.5 \%)$, phenyl acetylene $(98 \%)$, acetonitrile $(99.8 \%)$, sodium azide ( $\geq 99.5 \%)$, benzyl bromide $(98 \%)$, ethyl bromoacetate, N,N'dicyclohexyl carbodimide DCC (99\%) and methylene chloride were purchased from Sigma Aldrich and used without further purification. Azidomethyl phenyl and ethyl azidoacetate were prepared from sodium azide, benzyl bromide, and ethyl bromoacetate following published procedures [25-28]. X-Ray Diffraction (Thermo Scientific ARL 9900 XRF, France) was used to evaluate the Physico-chemical characteristics of washed and purified clays under study. Nuclear magnetic resonance spectroscopy (NMR) was recorded on a Bruker Avance $300 \mathrm{WB}$ spectrometer (Bruker, France) at $300 \mathrm{MHz}$ for the proton spectra $\left.\left({ }^{1} \mathrm{H}\right)\right)$ and $75.5 \mathrm{MHz}$ for the carbon spectra $\left({ }^{13} \mathrm{C}\right)$. Chemical shifts $(\delta)$ are indicated after calibration on the residual undeuterated solvent peak in part per million (ppm) and as follows: s (singlet), 
UV-Vis spectrophotometer BKUV $1600 \mathrm{PC}$ in $\mathrm{CH}_{2} \mathrm{Cl}_{2}$. The molecular masses of synthesized compounds were evaluated by LC-MS analyses using a Shimadzu LCSM-2010 A instrument equipped with an SPD-M10 A PDA diode array detector (D2, lamp from 190 to $400 \mathrm{~nm}$ ) and an ELSD-LT light scattering detector on an Altima HP C8 $3 \mu$ (Alltech) reversed-phase $(\mathrm{L}=53 \mathrm{~mm}$; ID $=7 \mathrm{~mm})$ HPLC column. The $\mathrm{LC}$ were ran using a $1 \mathrm{~mL} / \mathrm{min}$ flow using a gradient between acetonitrile and water containing formic acid (0,1\%): 0 to $1 \mathrm{~min}: 30 \% \mathrm{CH}_{3} \mathrm{CN}, 1$ to $5 \mathrm{~min}$ : from $30 \%$ to $100 \%$ $\mathrm{CH}_{3} \mathrm{CN}, 5$ to $12 \mathrm{~min}: 100 \% \mathrm{CH}_{3} \mathrm{CN}, 12$ to $14,99 \mathrm{~min}$ : from $100 \%$ to $30 \% \mathrm{CH}_{3} \mathrm{CN}, 14,99$ to $20 \mathrm{~min}: 30 \% \mathrm{CH}_{3} \mathrm{CN}$. MS was recorded between $\mathrm{m} / \mathrm{z}=100$ to 500 at the exit of the column using an ESI ionization and positive ion mode (detector $=1.5 \mathrm{kV}$, quadripole $=5 \mathrm{~V}$ ). Samples of clays from Gafsa were collected from two sites (Jebal Es Sath and Jebal Sehib).

\subsection{Preparation of ecological catalysts}

\subsubsection{Preparation of washed clay}

In $200 \mathrm{~mL}$ of distilled water, we add $100 \mathrm{~g}$ of raw powder clay. After stirring at $200 \mathrm{tr} / \mathrm{mn}$ at room temperature for one hour, centrifugation of obtained mixture was realized at $4000 \mathrm{tr} / \mathrm{mn}$. This same operation was repeated several times until clean water was obtained. The clay was dried at $50^{\circ} \mathrm{C}$ for 48 hours. The physicochemical characteristics of washed clays were evaluated by X-ray fluorescence (XRF) coupled with diffraction (XRD) on a Thermo Scientific ARL 9900 XRF series workstation and IR spectroscopy. The washed clay was ground and used as such in the catalytic coupling reaction of alkyne-azide.

\subsubsection{Preparation of Purified clay}

The purified clay was prepared by placing $20 \mathrm{~g}$ of the obtained washed clay in $400 \mathrm{~mL}$ of an aqueous sodium chloride solution $(1 \mathrm{M})$. The suspension was stirred $(100 \mathrm{rpm})$ for 12 hours before centrifuging (4000 rpm, $10 \mathrm{~min})$. The supernatant substance was removed, and the-process was repeated three other times with fresh molar $\mathrm{NaCl}$ solution (1M). The excess of $\mathrm{NaCl}$ was removed by stirring in water $(400 \mathrm{~mL}, 100 \mathrm{rpm}, 5 \mathrm{~min}$ ) and centrifugation (4000 rpm, 10 $\mathrm{min}$ ), followed by dialysis. The dialysis was performed on $2 \mathrm{~g}$ of samples suspended in $200 \mathrm{~mL}$ of distilled water placed in a dialysis membrane (cellulose, $20 \mathrm{~cm}$ long, $20.4 \mathrm{~mm}$ diameter, MWCO 6-8 kD) against $1 \mathrm{~L}$ of distilled water. The distilled water was changed, and free chloride ions precipitated using the silver nitrate test $\left(\mathrm{AgNO}_{3} ; 1 \mathrm{M}\right)$. After overnight standing, the suspension was dried at $50^{\circ} \mathrm{C}$ to obtain the purified clay [29]. The purification of washed clay consists of exchanging minerals ions $\left(\mathrm{Al}^{3+}, \mathrm{Fe}^{3+}, \mathrm{Ca}^{2+}, \mathrm{Mg}^{2+}, \mathrm{Cu}^{2+}\right.$ and $\left.\mathrm{K}^{+}\right)$by $\mathrm{Na}^{+}$.

\subsubsection{Preparation of adsorbed clay by copper (I) iodide}

Purified clay exchange minerals ions $\left(\mathrm{Al}^{3+}, \mathrm{Fe}^{3+}, \mathrm{Ca}^{2+}, \mathrm{Mg}^{2+}, \mathrm{Cu}^{2+}\right.$, and $\left.\mathrm{K}^{+}\right)$by $\mathrm{Na}^{+}$, dried as a thin film at $50^{\circ} \mathrm{C}$, and incubated for 3 hours in $45 \mathrm{mmol}$ of copper (I) iodide solution in acetonitrile at room temperature. After eliminating acetonitrile, the film was cut into pieces at $3 \mathrm{~mm}$ of dimensions and used directly in the catalytic reaction [26]. Ecological catalysts prepared in this present work are presented in (Table 1).

\subsection{Synthesis}

\subsection{1. synthesis of terminated alkynes (General method)}

To a stirred cold solution of aniline derivative $(10 \mathrm{mmol})$ at $0^{\circ} \mathrm{C}$; added dropwise $0.62 \mathrm{~mL}$ of propiolic acid $(0.62 \mathrm{~mL}$, $0.71 \mathrm{~g}, 10 \mathrm{mmol}, 1$ eq.) in $20 \mathrm{~mL}$ of $\mathrm{CH}_{2} \mathrm{Cl}_{2}$, followed by a solution of $2.58 \mathrm{~g}$ of DCC (12.5mmol, 1.25 eq.) in $20 \mathrm{~mL}$ of $\mathrm{CH}_{2} \mathrm{Cl}_{2}$. The reaction mixture was then stirred at $0^{\circ} \mathrm{C}$ for $0.5 \mathrm{~h}$ half an hour and overnight at room temperature. The mixture was then filtered through Celite onto the sintered glass. The Celite was washed with $\mathrm{CH}_{2} \mathrm{Cl}_{2}(20 \mathrm{~mL})$. The filtrate was then extracted with $\mathrm{HCl}(0.1 \mathrm{M} ; 2 \times 10 \mathrm{~mL})$ and $\mathrm{NaOH}(0.1 \mathrm{M} ; 2 \times 10 \mathrm{~mL})$. The obtained mixture was washed with distilled water $(3 \times 20 \mathrm{~mL})$ and dried over $\mathrm{MgSO}_{4}$. After filtration, the solvent was evaporated under a vacuum. The resulting amides $\mathbf{3 a}-\mathbf{4 a}$ (Scheme 1) were purified by column chromatography on silica gel using heptanes/ethyl acetate (1:1) [29]. Alkynes 1a and 2a were purchased from Sigma Aldrich.

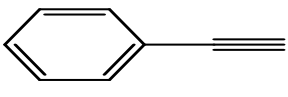

Pheny acetylen
(1 a)

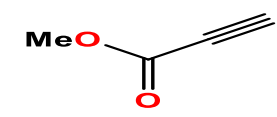

Methyl popiolate
(2a)

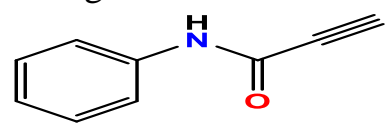

N-phenyl propiolamide

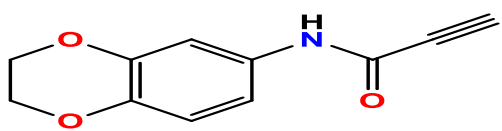

N-(2,3-dihydrobenzo $[1,4]$ dioxin-6-yl)propiolamide

Scheme-1: Structures of organic alkynes used $n$ the synthesis of 1,2,3-triazoles heterocycles.

\subsubsection{Synthesis of Azides (General method)}

Azides (1b-2b) were prepared from sodium azide, benzyl bromide, ethyl bromoacetate as described by [25-28] (Scheme 2).
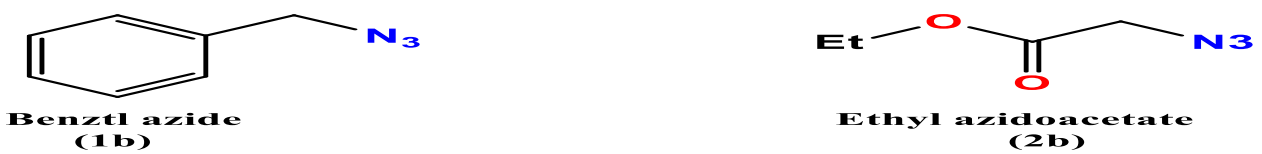

Scheme-2: Structures of azides used in the synthesis of 1,2,3-triazoles heterocycles.

\subsection{3. synthesis of $1,2,3$-Triazoles (General method)}

Triazoles (1a1b), (2a1b), (3a1b), (4a1b), (1a2b), (2a2b), (3a2b) and (4a2b) were prepared from $0.5 \mathrm{mmol}$ of terminated alkyne, $40 \mathrm{mg}$ of the studied catalyst and $0.5 \mathrm{mmol}$ of azide [29]. The mixture was maintained at room temperature 
without solvents and excitements. After 36 hours of reaction, we add $2 \mathrm{~mL}$ of $\mathrm{CH}_{2} \mathrm{Cl}_{2}$ to facilitate the removal of the catalyst by filtration. After evaporation of $\mathrm{CH}_{2} \mathrm{Cl}_{2}$ under vacuum, the obtained triazole was analyzed by ${ }^{1} \mathrm{HNMR}$ to evaluate the formation percentages of $(1,4)$ and $(1,5)$ isomers $[16,17]$ (Scheme 3).

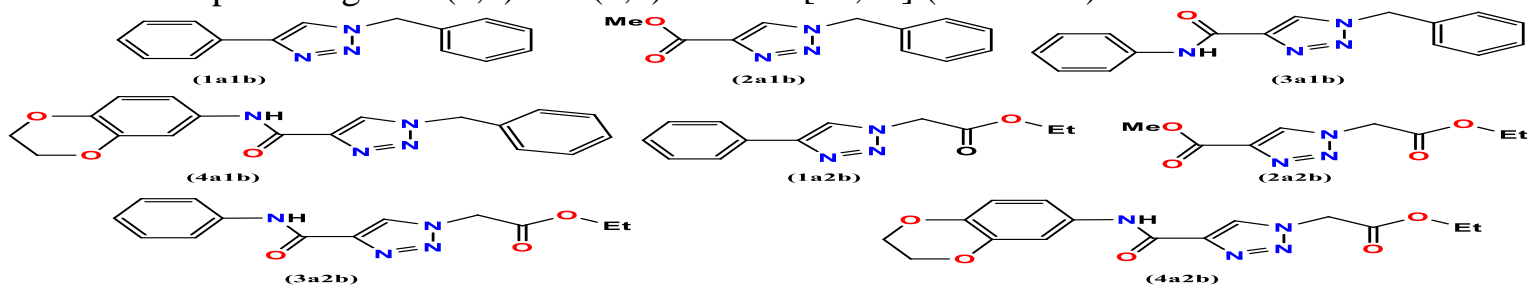

Scheme-3: Structures of 1,4-disubstituted-1,2,3-triazoles obtained from coupling reaction between organic alkynes (1a-4a) and azides (1b-2b) using ecological catalysts (Table 1).

\section{RESULTS AND DISCUSSION}

\subsection{Catalysts section}

Initially, six catalysts based on Tunisian clays were prepared to test their effects on synthesizing 1,2,3-triazoles (Table 1). Clays were collected from two well-known Tunisian deposits in Gafsa area: Jebal Sehib (JS) located at near M'dhilla, around $34^{\circ} 12^{\prime} \mathrm{N} / 8^{\circ} 42^{\prime}$ E) and Jebal Es Sath (JES) (located at between Gafsa Metlaoui, around $34^{\circ} 23^{\prime} \mathrm{N} / 8^{\circ} 31^{\prime} \mathrm{E}$ ) and of South East Tunisian. Fig.1 summarized the Preparation of ecological catalysts and their application in the synthesis of 1,2,3-triazoles.
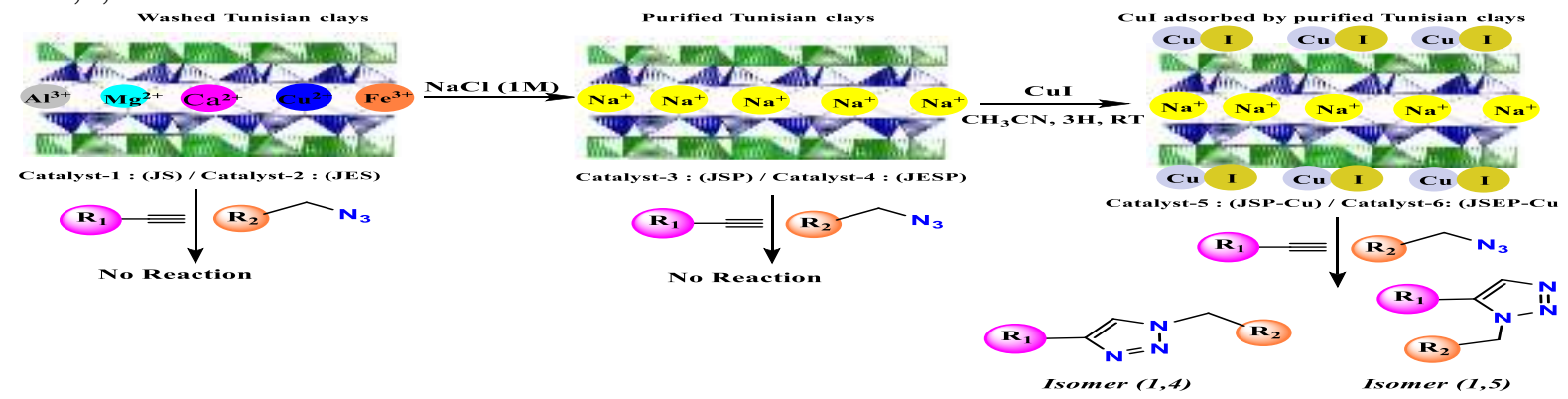

Fig-1: Preparation of Tunisian ecological clays used as catalysts.

Elemental compositions of washed clays were presented in (Table 2) while results of XR Diffraction of washed and purified clays were tabulated in (Table 3) and their IR spectroscopies were presented in (Table 4).

Table-1: Catalysts used for the synthesis of 1,2,3-triazoles molecules.

\begin{tabular}{|c|l|}
\hline Species & Clay used to prepare catalyst \\
\hline JS & Washed clay taken from Jebal Shib \\
\hline JES & Washed clay taken from Jebal Es Sath \\
\hline JSP & Clay of Jebal Shib purified by $\mathrm{Na}^{+}$ \\
\hline JESP & Clay of Jebal Es Sath purified by $\mathrm{Na}^{+}$ \\
\hline JSP-Cu & CuI adsorbed by purified clay of Jebal Shib \\
\hline JSEP-Cu & CuI adsorbed by purified clay of Jebal Es Sath \\
\hline
\end{tabular}

Table-2: Elementary compositions of washed clays from Jebal Es Sath and Jebal Sehib [29].

\begin{tabular}{|c|c|c|c|c|c|c|c|c|c|}
\hline Elements $^{\mathbf{a}}$ & $\mathbf{S i O}_{\mathbf{2}}$ & $\mathbf{A l}_{\mathbf{2}} \mathbf{O}_{\mathbf{3}}$ & $\mathbf{F e}_{\mathbf{2}} \mathbf{O}_{\mathbf{3}}$ & $\mathbf{M g O}$ & $\mathbf{S O}_{\mathbf{3}}$ & $\mathbf{K}_{\mathbf{2}} \mathbf{O}$ & $\mathbf{P}_{\mathbf{2}} \mathbf{O}_{\mathbf{5}}$ & $\mathbf{N a}$ & $\mathbf{L I}^{\mathbf{b}}$ \\
\hline $\mathbf{J S}$ & 43.34 & 21.48 & 7.90 & 2.96 & 2.03 & 0.86 & 0.36 & 0.65 & 9.28 \\
\hline $\mathbf{J E S}$ & 39.52 & 19.87 & 15.06 & 7.87 & 2.87 & 0.915 & 0.23 & 0.35 & 9.28 \\
\hline
\end{tabular}

a: Composition in Wt \%

b: Loss Ignition

Table-3: Results of XR Diffraction of washed and purified studied clays [29].

\begin{tabular}{|c|l|}
\hline Species & Rays $(\mathbf{\AA})$ \\
\hline JS & $14.65,7.01,4.93,4.39,4.18,3.51,3.30$ \\
\hline JES & $12.31,6.81,3.98,3.49,3.11$ \\
\hline JSP & $12.31,6.93,3.53$ \\
\hline JESP & $11.80,3.98,3.12$ \\
\hline
\end{tabular}

X-ray diffraction (XRD) of (JES) showed a typical ray of smectite clay-rich with $(12.31 \AA$ and $3.98 \AA)$, probably a Montmorillonite $\left[(\mathrm{Na}, \mathrm{Ca})_{0,3}\left(\mathrm{Al}, \mathrm{Fe}, \mathrm{Mg}_{2}\right)_{2} \mathrm{Si}_{4} \mathrm{O}_{10}(\mathrm{OH})_{2} \cdot \mathrm{nH}_{2} \mathrm{O}\right]$, containing kaolinite $\left(\mathrm{Al}_{2} \mathrm{Si}_{2} \mathrm{O}_{5}(\mathrm{OH})_{4} ; 6.81 \AA\right.$ and $\left.3.49 \AA\right)$. After purification (JES), the XRD recorded was quite similar but characterized for sodium smectite (11.80 ̊ and 3.98 $\AA$ ). In the case of (JS) clay, the XRD was typical of smectite rich with calcium (Montmorillonite, $14.65 \AA$ ), with kaolinite (7.01 $\AA$ and $3.51 \AA$ ), quartz $\left(\mathrm{SiO}_{2} ; 4.18 \AA\right.$ and $3.30 \AA$ ), and other impurities. Once purification was conducted on (JS), 


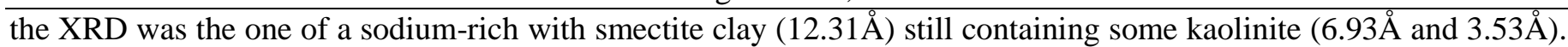
For clays activated by copper iodide (I) (JSP-Cu and JESP-Cu), the results of XRD were similar to those observed for the purified clays (JSP and JESP) [29].

Table-4: IR spectroscopy of washed and purified studied clays [29].

\begin{tabular}{|c|l|}
\hline Species & IR observed bands \\
\hline JS & $v\left(\mathrm{~cm}^{-1}\right): 3645(\mathrm{Al}-\mathrm{Al}-\mathrm{OH}), 1642\left(\mathrm{H}_{2} \mathrm{O}\right), 1442($ calcite $), 1034(\mathrm{SiO})$ \\
\hline JES & $v\left(\mathrm{~cm}^{-1}\right): 3641(\mathrm{Al}-\mathrm{Al}-\mathrm{OH}), 1644\left(\mathrm{H}_{2} \mathrm{O}\right), 1442($ calcite $), 1034(\mathrm{SiO})$ \\
\hline JSP & $v\left(\mathrm{~cm}^{-1}\right): 3647(\mathrm{Al}-\mathrm{Al}-\mathrm{OH}), 1640\left(\mathrm{H}_{2} \mathrm{O}\right), 1030(\mathrm{SiO})$ \\
\hline JESP & $v\left(\mathrm{~cm}^{-1}\right): 3644(\mathrm{Al}-\mathrm{Al}-\mathrm{OH}), 1643\left(\mathrm{H}_{2} \mathrm{O}\right), 1036(\mathrm{SiO})$ \\
\hline
\end{tabular}

In ATR/FTIR results of studied clays (Table 4), the bands observed at $3641 \mathrm{~cm}^{-1}$ is attributed to the $\mathrm{Al}-\mathrm{Al}-\mathrm{OH}$ vibration and those observed at $1644 \mathrm{~cm}^{-1}$ correspond to $\mathrm{OH}$ frequency for the water molecule adsorbed on the clay surface, as well as those for $\mathrm{SiO}$ at $1034 \mathrm{~cm}^{-1}$. Washed clays displayed bands relative to calcite $\left(1442 \mathrm{~cm}^{-1}\right)$ which are absent from the purified clays. These results and DRX analyses (Table 3) confirmed the purification and sodium exchange of the clays [29]. For clays activated by copper (I) (JSP-Cu and JESP-Cu), the results of IR spectroscopy were similar to those observed for the purified clays (JSP and JESP).

\subsection{Synthesis section}

In the second step, the coupling reaction between terminal alkynes and azides in the presence of fresh last prepared catalysts (Table 1), without solvents and without enthusiasms at room temperature during 36 hours were carried out. The coupling of alkynes (1a-4a) with azides (1b-2b) in the presence of catalysts (JS, JES, JSP, JESP, JSP-Cu, and JSEP$\mathrm{Cu}$ ) at room temperature without solvents and excitements gave two isomers $(1,4)$ and (1,5)-disubstituted-1,2,3-triazoles (Scheme 3). The yields of isomers $(1,4)$ and $(1,5)$ were evaluated by ${ }^{1} \mathrm{HNMR}$ conversion; results of ${ }^{1} \mathrm{HNMR}$ conversion were given in Tables ( $3 \& 4)$.

Table-3: Conversion ${ }^{1}$ HNMR of 1,4 and 1,5 isomers obtained during coupling reaction between alkynes 1a-4a and azide $\mathbf{1 b}$ using prepared Tunisian ecological catalysts.

\begin{tabular}{|c|c|c|c|c|}
\hline Entry & Triazoles & Catalysts & $\begin{array}{c}\text { Conversion (\%) of Isomer } \\
(1,4)\end{array}$ & $\begin{array}{c}\text { Conversion (\%) of Isomer } \\
(1,5)\end{array}$ \\
\hline 1 & \multirow{7}{*}{ (1a1b) } & No one* & 0 & 0 \\
\hline 2 & & JS & 0 & 0 \\
\hline 3 & & JES & 0 & 0 \\
\hline 4 & & JSP & 0 & 0 \\
\hline 5 & & JESP & 0 & 0 \\
\hline 6 & & JSP-Cu & 100 & 0 \\
\hline 7 & & JSEP-Cu & 100 & 0 \\
\hline 8 & \multirow{7}{*}{ (2a1b) } & No one * & 87.6 & 12.4 \\
\hline 9 & & JS & 89.9 & 10.1 \\
\hline 10 & & JES & 90.6 & 9.4 \\
\hline 11 & & JSP & 92.2 & 7.8 \\
\hline 12 & & JESP & 92 & 8 \\
\hline 13 & & JSP-Cu & 100 & 0 \\
\hline 14 & & JSEP-Cu & 94.8 & 5.2 \\
\hline 15 & \multirow{7}{*}{ (3a1b) } & No one* & 61.6 & 38.4 \\
\hline 16 & & JS & 55.6 & 44.4 \\
\hline 17 & & JES & 75.8 & 24.2 \\
\hline 18 & & JSP & 76.7 & 23.3 \\
\hline 19 & & JESP & 63 & 37 \\
\hline 20 & & JSP-Cu & 84.2 & 15.8 \\
\hline 21 & & JSEP-Cu & 84.8 & 15.2 \\
\hline 22 & & No one* & 84.4 & 15.6 \\
\hline 23 & & JS & 83.3 & 16.7 \\
\hline
\end{tabular}


Pakistan Journal of Chemistry 2021

\begin{tabular}{|c|c|c|c|c|}
\hline 24 & \multirow{5}{*}{$(4 a 1 b)$} & JES & 78 & 22 \\
\hline 25 & & JSP & 78.8 & 21.2 \\
\hline 26 & & JESP & 92.1 & 7.9 \\
\hline 27 & & JSP-Cu & 100 & 0 \\
\hline 28 & & JSEP-Cu & 100 & 0 \\
\hline
\end{tabular}

*Reaction without catalyst

Table-4: Conversion ${ }^{1}$ HNMR of 1,4 and 1,5 isomers obtained during coupling reaction between alkynes 1a-4a and azide $\mathbf{2 b}$ using prepared Tunisian ecological catalysts.

\begin{tabular}{|c|c|c|c|c|}
\hline Entry & Triazoles & Catalysts & Conversion $(\%)$ of Isomer $(1,4)$ & Conversion $(\%)$ of Isomer $(1,5)$ \\
\hline 1 & \multirow{7}{*}{$(1 \mathbf{a} 2 b)$} & No one * & 0 & 0 \\
\hline 2 & & JS & 0 & 0 \\
\hline 3 & & JES & 0 & 0 \\
\hline 4 & & JSP & 0 & 0 \\
\hline 5 & & JESP & 0 & 0 \\
\hline 6 & & JSP-Cu & 100 & 0 \\
\hline 7 & & JSEP-Cu & 100 & 0 \\
\hline 8 & \multirow{7}{*}{$(2 \mathbf{a} 2 \mathbf{b})$} & No one* & 88.2 & 11.8 \\
\hline 9 & & JS & 93.6 & 6.4 \\
\hline $\mathbf{1 0}$ & & JES & 93.3 & 6.7 \\
\hline 11 & & JSP & 90.3 & 9.7 \\
\hline 12 & & JESP & 86.3 & 13.7 \\
\hline 13 & & JSP-Cu & 98.6 & 1.4 \\
\hline 14 & & JSEP-Cu & 96.7 & 3.3 \\
\hline 15 & \multirow{7}{*}{$(3 \mathbf{a} 2 b)$} & No one* & 78.5 & 21.5 \\
\hline 16 & & JS & 77.3 & 22.7 \\
\hline 17 & & JES & 79.1 & 20.9 \\
\hline 18 & & JSP & 76.5 & 23.5 \\
\hline 19 & & JESP & 77.7 & 22.3 \\
\hline 20 & & JSP-Cu & 94.5 & 5.5 \\
\hline 21 & & JSEP-Cu & 100 & 0 \\
\hline 22 & \multirow{7}{*}{$(4 a 2 b)$} & No one* & 71.9 & 28.1 \\
\hline 23 & & JS & 69.9 & 30.1 \\
\hline 24 & & JES & 61.8 & 38.1 \\
\hline 25 & & JSP & 72.7 & 27.3 \\
\hline 26 & & JESP & 61 & 39 \\
\hline 27 & & JSP-Cu & 100 & 0 \\
\hline 28 & & JSEP-Cu & 100 & 0 \\
\hline
\end{tabular}

*Reaction without catalyst

Results showed that no reaction took place (Tables $3 \& 4$, Entries: 1, 2, 3, 4, 5) in the reaction between phenylacetylene (1a) and azidomethyl phenyl (1b) and/or ethyl azidoacetate (2b) without catalyst and/or using the catalysts (JS, JES, 
JSP, and JESP). The mineral elements $\left(\mathrm{SiO}_{2}, \mathrm{Al}_{2} \mathrm{O}_{3}, \mathrm{Fe}_{2} \mathrm{O}_{3}, \mathrm{MgO}, \mathrm{CaO}, \mathrm{SO}_{3}, \mathrm{P}_{2} \mathrm{O}_{5}, \mathrm{~K} 2 \mathrm{O}\right.$, and $\left.\mathrm{Na}\right)$ that constituents of washed clays (Table 2) do not affect the coupling reaction between terminal alkynes and azides. The outcome was $0 \%$ for the two isomers $(1,4)$ and $(1,5)$. The coupling reaction between alkynes $(\mathbf{1 a - 4 a})$ and azides $(\mathbf{1 b}$-2/b) using adsorbed $\mathrm{CuI}$ by purified clays (Cu-pillared clay) was regioselective for 1,4-disubstituted-1,2,3-triazole, the yields of $(1,4)$ isomer were approximately 100\% (Table 3, Entries: 6, 7, 13, 27 and 28 \& Table 4, Entries: 6, 7, 21, 27 and 28). These results were in agreement with those obtained by Elamari et al. [16]. The yield obtained for the $(1,4)$ isomer using CuI adsorbed by purified Tunisian clays is better than that obtained by Prabakaran et al. [30]. They used synthetic catalysts with copper (II) for coupling phenylacetylene and benzyl azide (yield $\leq 93 \%$ ). The yields of $(1,4)$ and $(1,5)$ isomers obtained from application catalysts (JS, JES, JSP, and JESP) in the coupling alkynes (1a-4a) and azides (1b-2b) were similar to the reaction realized without catalyst, the maximum yield obtained for the isomer $(1,4)$ was in the order of $93.6 \%$ with (JES) catalyst (Table 4, Entry: 10) and it is in the order of 44.4\% for (1,5) isomer with (JS) catalyst (Table 3, Entry: 16). In general, the yields of isomer $(1,4)$ and $(1,5)$ obtained by catalysts (JS, JES, JSP, JESP) are in agreement with these obtained from reaction carried without catalyst realized at the same conditions (Tables $3 \& 4$, Entries: 1). In this context, washed and purified clays have no effect on the coupling alkynes-azides. In general, the (1,4)-disubstituted-1,2,3triazole was predominantly obtained, these results were comparable to those obtained by Jlalia et al. [26], they applied catalysts (Why-Crude) and (Why-Na) for coupling benzylazide and methyl propiolate, They observed the formation of the two isomers $(1,4)$ and $(1,5)$ with a favor for $(1,4)$-disubstituted-1,2,3-triazole. Practically, the use of copper (I) adsorbed by purified Tunisian clays (Catalysts JSP-Cu \& JSEP-Cu) in the reaction between alkynes (1a-4a) and azides $(1 b-2 b)$ gives complete regioselectivity for the isomer $(1,4)$, which is in agreement with the results found in the literature $[16,17]$. A comparison of the effect of the two Cu-pillared clay (JSP-Cu \& JESP-Cu) on the coupling alkynes-azides (Fig.2), revealed that the two catalysts are similar, the percentages obtained for the $(1,4)$ isomer by (JSP-Cu \& JESP$\mathrm{Cu}$ ) were $97.16 \pm 5.57 \%$ and $97.03 \pm 5.32 \%$, respectively. The maximum percentages obtained for $(1,5)$ isomers using the same catalysts were in the order of 15.8 and $15.2 \%$, respectively. These results explain that the two purified clays (JSP) and (JESP) were adsorbed the same quantity of CuI.

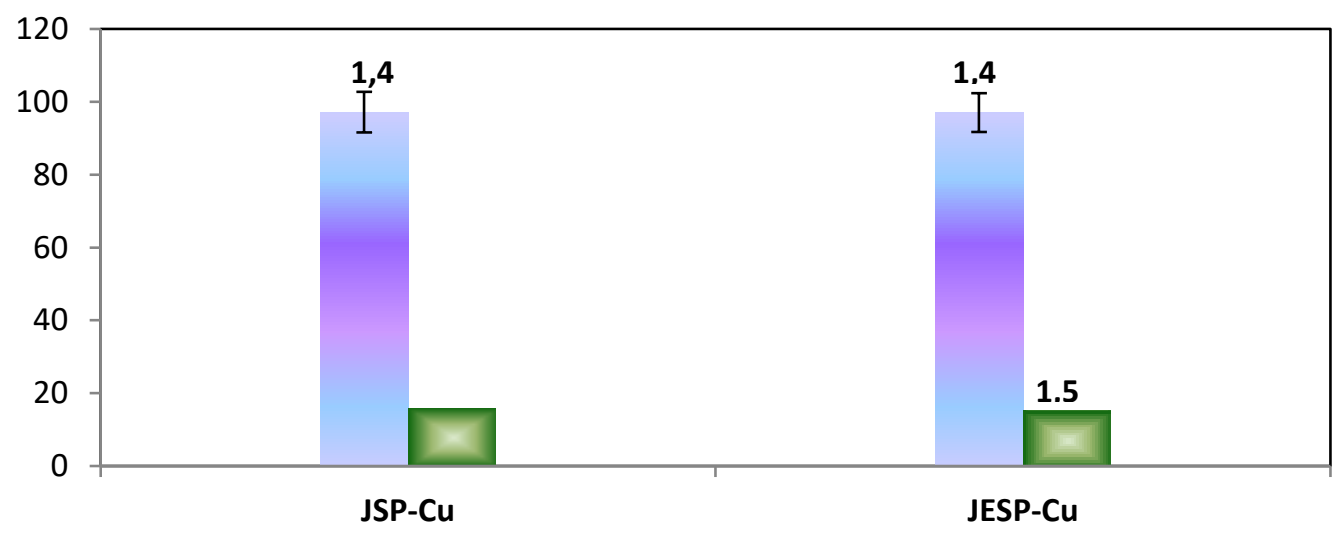

Fig-2. Percentages of $(1,4)$ and $(1,5)$ isomers were obtained during the application of ecological catalysts (JSP-Cu) and (JESP-Cu).

\subsection{Analysis section}

Benzyl azide (1b): yield 94\%, IR $\left(v \mathrm{~cm}^{-1}\right)$ : 3042(Car-H), 2986-2869 $\left(\mathrm{CH}_{2}\right), 2093\left(\mathrm{~N}_{3}\right), 1453 .{ }^{1} \mathrm{H} \mathrm{NMR}\left(\mathrm{CDCl}_{3}\right): \delta 4.38$ $(\mathrm{s}, 2 \mathrm{H})$ and 7.35-7.46 (m, 5H). ${ }^{13} \mathrm{C} \mathrm{NMR}\left(\mathrm{CDCl}_{3}\right): \delta 55.2,128.7,129.1,129.3,135.9$.

Ethyl azidoacetate (2b): yield 84\%, IR $\left(\mathrm{v} \mathrm{cm}^{-1}\right): 2992-2866\left(\mathrm{CH}_{2}\right), 2100\left(\mathrm{~N}_{3}\right), 1737(\mathrm{C}=\mathrm{O}) .{ }^{1} \mathrm{H} \mathrm{NMR}\left(\mathrm{CDCl}_{3}\right): \delta 1.27$ $(\mathrm{t}, 3 \mathrm{H}, \mathrm{J}=7.1 \mathrm{~Hz}), 3.83(\mathrm{~s}, 2 \mathrm{H})$ and $4.22(\mathrm{q}, 2 \mathrm{H}, \mathrm{J}=7.1 \mathrm{~Hz}) .{ }^{13} \mathrm{C} \mathrm{NMR}\left(\mathrm{CDCl}_{3}\right): \delta 14.2,50.1,61.0$ and 167.4.

N-phenylpropiolamide (3a): yield 63\%, IR $\left(v \mathrm{~cm}^{-1}\right)$ : 3342(NH), $2110(\mathrm{C} \equiv \mathrm{CH}), 1746(\mathrm{C}=\mathrm{O}) .{ }^{1} \mathrm{H}$ NMR $\left(\mathrm{CDCl}_{3}\right): \delta 2.96$ $(\mathrm{s}, 1 \mathrm{H}), 7.17-7.22(\mathrm{~m}, 1 \mathrm{H}), 7.31-7.40(\mathrm{~m}, 2 \mathrm{H}), 7.56-7.59(\mathrm{~m}, 2 \mathrm{H})$ and $7.96(\mathrm{~s}, 1 \mathrm{H}) .{ }^{13} \mathrm{C} \mathrm{NMR}\left(\mathrm{CDCl}_{3}\right): \delta 74.2,78,119.1$, 125.6, 128.9, 137.7 and 153. LC-MS calculated for $\mathrm{C}_{9} \mathrm{H}_{7} \mathrm{NO}$, m.wt 145.16, m/z: $146[\mathrm{M}+\mathrm{H}]^{+}$.

\section{N-(2,3-dihydrobenzo[1,4]-dioxin-6-yl) propiolamide (4a):}

yield 69\%, IR $\left(v^{-1} \mathrm{~cm}^{-1}\right): 3262(\mathrm{NH}), 2109(\mathrm{C} \equiv \mathrm{CH}), 1641(\mathrm{C}=\mathrm{O}) .{ }^{1} \mathrm{H}$ NMR (DMSO-d 6$)$ : $\delta 4.23(\mathrm{~S}, 4 \mathrm{H}), 4.37(\mathrm{~s}, 1 \mathrm{H}), 6.82$ $(\mathrm{d}, \mathrm{J}=8.72 \mathrm{~Hz}, 1 \mathrm{H}), 7.04(\mathrm{~d}, \mathrm{~J}=8.72 \mathrm{~Hz}, 1 \mathrm{H}), 7.22(\mathrm{~s}, 1 \mathrm{H})$ and $10.66(\mathrm{~s}, 1 \mathrm{H}) .{ }^{13} \mathrm{C}$ NMR $\left(\mathrm{DMSO}_{-} \mathrm{d}_{6}\right): \delta 64.45,64.66,77.29$, 78.97, 109.35, 113.44, 117.36, 132.32, 140.53, 143.40 and 149.73. LC-MS calculated for $\mathrm{C}_{11} \mathrm{H}_{9} \mathrm{NO}_{3}$, m.wt 203.18, m/z: $204[\mathrm{M}+\mathrm{H}]^{+}$. 1-Benzyl-4-phenyl-1H-1,2,3-triazole (1a1b): yield 88\%, IR $\left(\mathrm{v} \mathrm{cm}^{-1}\right): 3095(\mathrm{Car}-\mathrm{H}), 2987\left(\mathrm{CH}_{2}\right), 1610-$ $1547(\mathrm{C}=\mathrm{C}), 1453(\mathrm{~N}=\mathrm{N})$. LC-MS calculated for $\mathrm{C}_{15} \mathrm{H}_{13} \mathrm{~N}_{3}$, m.wt 235.29, m/z: $236[\mathrm{M}+\mathrm{H}]^{+} .{ }^{1} \mathrm{H}$ NMR $\left(\mathrm{CDCl}_{3}\right): \delta 5.6 \mathrm{~s}$, $2 \mathrm{H}) ; 7.32-7.45(\mathrm{~m}, 8 \mathrm{H}) ; 7.71(\mathrm{~s}, 1 \mathrm{H})$ and $7.82-7.85(\mathrm{~m}, 2 \mathrm{H})$. UV (MeOH, $\left.\lambda_{\max } \mathrm{nm}, \varepsilon_{\max } \mathrm{L}_{\mathrm{mol}}{ }^{-1} . \mathrm{cm}^{-1}\right): 338,3984, \mathrm{n} \rightarrow \pi^{*}$. Ethyl-2-(4-phenyl-1H-1,2,3-triazol-1-yl) acetate (1a2b): yield 91\%, IR $\left(v \mathrm{~cm}^{-1}\right): 3005(\mathrm{Car}-\mathrm{H}), 2952\left(\mathrm{CH}_{2}\right), 1727$ $(\mathrm{C}=\mathrm{O}), 1605-1535(\mathrm{C}=\mathrm{C}), 1426(\mathrm{~N}=\mathrm{N})$. LC-MS calculated $\mathrm{C}_{12} \mathrm{H}_{13} \mathrm{~N}_{3} \mathrm{O}_{2}$, m.wt 231.25, m/z: $232[\mathrm{M}+\mathrm{H}]^{+}$. ${ }^{1} \mathrm{H}$ NMR 
$\left(\mathrm{CDCl}_{3}\right): \delta 1.34(\mathrm{t}, 3 \mathrm{H}) ; 4.29(\mathrm{q}, 2 \mathrm{H}) ; 5.23(\mathrm{~s}, 2 \mathrm{H}) ; 7.43-7.89(\mathrm{~m}, 5 \mathrm{H})$ and $7.96(\mathrm{~s}, 1 \mathrm{H}) . \mathrm{UV}\left(\mathrm{MeOH}, \lambda_{\max } \mathrm{nm}, \varepsilon_{\max } \mathrm{L} \mathrm{mol}^{-}\right.$ $\left.{ }^{1} . \mathrm{cm}^{-1}\right): 340,3872, \mathrm{n} \rightarrow \pi^{*}$

Methyl-1-benzyl-1H-1,2,3-triazole-4-carboxylate (2a1b): yield 96\%, IR $\left(v \mathrm{~cm}^{-1}\right): 3112(\mathrm{Car}-\mathrm{H}), 2952\left(\mathrm{CH}_{2}\right), 1721$ $(\mathrm{C}=\mathrm{O}), 1537(\mathrm{C}=\mathrm{C}), 1433(\mathrm{~N}=\mathrm{N})$. LC-MS calculated $\mathrm{C}_{11} \mathrm{H}_{11} \mathrm{~N}_{3} \mathrm{O}_{2}, \mathrm{~m} . \mathrm{wt} 217.23, \mathrm{~m} / \mathrm{z}: 218[\mathrm{M}+\mathrm{H}]^{+} .{ }^{1} \mathrm{H}$ NMR $\left(\mathrm{CDCl}_{3}\right)$ : $\delta 3.96(\mathrm{~s}, 3 \mathrm{H}) ; 5.61(\mathrm{~s}, 2 \mathrm{H}) ; 7.30-7.44(\mathrm{~m}, 5 \mathrm{H})$ and $8.01(\mathrm{~s}, 1 \mathrm{H}) . \mathrm{UV}\left(\mathrm{MeOH}, \lambda_{\max } \mathrm{nm}, \varepsilon_{\max } \mathrm{L}_{\mathrm{mol}}{ }^{-1} . \mathrm{cm}^{-1}\right): 337,3894$, $\mathrm{n} \rightarrow \pi^{*}$

Methyl-1-(2-ethoxy-2-oxoethyl)-1H-1,2,3-triazole-4-carboxylate (2a2b): yield 92\%, IR ( $\left.v_{\text {cm }}{ }^{-1}\right)$ : 3010 (Car-H), 2945 $\left(\mathrm{CH}_{2}\right), 1730(\mathrm{C}=\mathrm{O}), 1546(\mathrm{C}=\mathrm{C}), 1425(\mathrm{~N}=\mathrm{N})$. LC-MS calculated $\mathrm{C}_{8} \mathrm{H}_{11} \mathrm{~N}_{3} \mathrm{O}_{4}$, m.wt 213.19, m/z: $214[\mathrm{M}+\mathrm{H}]^{+} .{ }^{1} \mathrm{H}$ NMR $\left(\mathrm{CDCl}_{3}\right): \delta 1.27(\mathrm{t}, 3 \mathrm{H}) ; 3.92(\mathrm{~s}, 3 \mathrm{H}) ; 4.26(\mathrm{q}, 2 \mathrm{H}) ; 5.25(\mathrm{~s}, 2 \mathrm{H})$ and $8.31(\mathrm{~s}, 1 \mathrm{H})$. UV (MeOH, $\lambda_{\max } \mathrm{nm}, \varepsilon_{\max } \mathrm{L} \mathrm{mol}^{-}$ $\left.{ }^{1} . \mathrm{cm}^{-1}\right): 340,4000, \mathrm{n} \rightarrow \pi^{*}$

1-benzyy-N-phenyl-1H-1,2,3-triazole-4-carboxamide (3a1b) : yield 90\%, IR $\left(v \mathrm{~cm}^{-1}\right): 3005(\mathrm{Car}-\mathrm{H}), 2965\left(\mathrm{CH}_{2}\right)$, $1754(\mathrm{C}=\mathrm{O}), 1597-1552(\mathrm{C}=\mathrm{C}), 1433(\mathrm{~N}=\mathrm{N})$. LC-MS calculated $\mathrm{C}_{16} \mathrm{H}_{14} \mathrm{~N}_{4} \mathrm{O}$, m.wt 278.31, m/z: $279[\mathrm{M}+\mathrm{H}]^{+}$. ${ }^{1} \mathrm{H}$ NMR $\left(\mathrm{CDCl}_{3}\right): \delta 6.2(\mathrm{~s}, 2 \mathrm{H}) ; 7.18-7.23(\mathrm{~m}, 10 \mathrm{H}) ; 7.81(\mathrm{~s}, 1 \mathrm{H})$ and $8.98(\mathrm{~s}, 1 \mathrm{H})$. UV $\left(\mathrm{MeOH}, \lambda_{\max } \mathrm{nm}, \varepsilon_{\max } \mathrm{L} . \mathrm{mol}^{-1} . \mathrm{cm}^{-1}\right): 340$, $5286, \mathrm{n} \rightarrow \pi^{*}$

Ethyl-2-[4-(phenylcarbamoyl)-1H-1,2,3-triazol-1-yl]acetate (3a2b) : yield 67\%, IR ( $\left.\mathrm{v} \mathrm{cm}^{-1}\right): 3030(\mathrm{Car}-\mathrm{H}), 2980$ $\left(\mathrm{CH}_{2}\right), 1750(\mathrm{C}=\mathrm{O}), 1651-1559(\mathrm{C}=\mathrm{C}), 1430(\mathrm{~N}=\mathrm{N})$. LC-MS calculated $\mathrm{C}_{13} \mathrm{H}_{14} \mathrm{~N}_{4} \mathrm{O}_{3}$, m.wt 274.28, m/z: $275[\mathrm{M}+\mathrm{H}]^{+}$. ${ }^{1} \mathrm{H}$ NMR $\left(\mathrm{CDCl}_{3}\right): \delta 1.35(\mathrm{t}, 3 \mathrm{H}) ; 4.33(\mathrm{q}, 2 \mathrm{H}) ; 5.27(\mathrm{~s}, 2 \mathrm{H}) ; 7.22-7.44(\mathrm{~m}, 5 \mathrm{H}) ; 8.33(\mathrm{~s}, 1 \mathrm{H})$ and $8.98(\mathrm{~s}, 1 \mathrm{H})$. UV $\left(\mathrm{MeOH}, \lambda_{\max } \mathrm{nm}, \varepsilon_{\max } \mathrm{L} \cdot \mathrm{mol}^{-1} \cdot \mathrm{cm}^{-1}\right): 342,5143, \mathrm{n} \rightarrow \pi^{*}$

1-benzyl-N-(2,3-dihydrobenzo[b][1,4]dioxin-6-yl)-1H-1,2,3-triazole-4-carboxamide (4a1b): yield 77\%, IR $\left(v \mathrm{~cm}^{-1}\right)$ : $3034(\mathrm{Car}-\mathrm{H}), 2942\left(\mathrm{CH}_{2}\right), 1730(\mathrm{C}=\mathrm{O}), 1650-1570(\mathrm{C}=\mathrm{C}), 1465(\mathrm{~N}=\mathrm{N})$. LC-MS calculated $\mathrm{C}_{18} \mathrm{H}_{16} \mathrm{~N}_{4} \mathrm{O}_{3}$, m.wt 336.35, $\mathrm{m} / \mathrm{z}: 337[\mathrm{M}+\mathrm{H}]^{+} .{ }^{1} \mathrm{H}$ NMR $\left(\mathrm{CDCl}_{3}\right): \delta 4.39(\mathrm{~s}, 4 \mathrm{H}) ; 5.61(\mathrm{~s}, 2 \mathrm{H}) ; 6.86-7.36(\mathrm{~m}, 8 \mathrm{H}) ; 8.07(\mathrm{~s}, 1 \mathrm{H})$ and $8.84(\mathrm{~s}, 1 \mathrm{H}) . \mathrm{UV}$ $\left(\mathrm{MeOH}, \lambda_{\max } \mathrm{nm}, \varepsilon_{\max } \mathrm{L} \cdot \mathrm{mol}^{-1} \cdot \mathrm{cm}^{-1}\right): 341,4758, \mathrm{n} \rightarrow \pi^{*}$

Ethyl-2-\{4-[(2,3-dihydrobenzo[b][1,4] dioxin-6-yl)carbamoyl]-1H-1,2,3-triazol-1-yl\}acetate (4a2b): yield 96\%, IR $\left(v \mathrm{~cm}^{-1}\right): 3039(\mathrm{Car}-\mathrm{H}), 2951\left(\mathrm{CH}_{2}\right), 1722(\mathrm{C}=\mathrm{O}), 1610-1570(\mathrm{C}=\mathrm{C}), 1452(\mathrm{~N}=\mathrm{N})$. LC-MS calculated $\mathrm{C}_{15} \mathrm{H}_{16} \mathrm{~N}_{4} \mathrm{O}_{5}$, m.wt $332.31, \mathrm{~m} / \mathrm{z}: 333[\mathrm{M}+\mathrm{H}]^{+} .{ }^{1} \mathrm{H}$ NMR $\left(\mathrm{CDCl}_{3}\right): \delta 1.34(\mathrm{~s}, 3 \mathrm{H}) ; 4.28-4.40(\mathrm{~m}, 6 \mathrm{H}) ; 5.25(\mathrm{~s}, 2 \mathrm{H}) ; 6.85-7.37(\mathrm{~m}, 3 \mathrm{H}) ; 8.33$ $(\mathrm{s}, 1 \mathrm{H})$ and $8.84(\mathrm{~s}, 1 \mathrm{H})$. UV (MeOH, $\left.\lambda_{\max } \mathrm{nm}, \varepsilon_{\max } \mathrm{L} \cdot \mathrm{mol}^{-1} \cdot \mathrm{cm}^{-1}\right): 340,4714, \mathrm{n} \rightarrow \pi^{*}$

\section{CONCLUSION}

For ecological reasons, we have prepared some green catalysts for testing them in the synthesis of 1,2,3-triazoles with biological activities. These catalysts were prepared from Tunisian clays taken from Gafsa region. The reaction of synthesis of 1,2,3-triazoles was studied during 36 hours at room temperature without solvents and excitements. Catalysts prepared from adsorbed $\mathrm{CuI}$ by purified clays have given regioselectivity for 1,4-disubstituted-1,2,3-triazole. These prepared catalysts are recyclable for other applications. The characterization techniques used in this work were: X-ray diffraction, IR spectroscopy for ecological catalysts. ${ }^{1} \mathrm{HNMR},{ }^{13} \mathrm{CNMR}$, Infrared (IR), and Ultraviolet spectroscopy for triazoles. LC-MS analyses evaluated the molecular masses of synthesized triazoles.

\section{ACKNOWLEDGMENTS}

This humble work is dedicated to Mr. Faouzi Meganem (Professor Emeritus at the Faculty of Sciences of Bizerte: Tunisia) as a token of gratitude.

\section{REFERENCES}

1. M. S. Malik, S. Ahmed, I. I. Althagafi, M. A. Ansari and A. Kamal, R.S.C. Med. Chem. 11(3), 327-348. (2020)

2. C. B.Vagisha, K. Kumara, H. K.Vivek, S. Bharathe, N. K. Lokanath and K. A. Kumar, J. Mol. Struct. 1230, 129899. (2021)

3. S. Mnasri, N. Besbes, N. Frini-Srasra and E. Srasra E, C. R. Chimie, 15, 437-443. (2012)

4. K. Alali, F. Lebsir, S. Amri, A. Rahmouni, E. Srasra and N. Besbes, Bull. Chem. React. Eng. Catal. 14(1), 130-141. (2019)

5. S. Amri, J. Gómez, A. Balea, N. Merayo, E. Srasra, N. Besbes and M. Ladero, Appl. Sci. 9(21), 4488. (2019)

6. W. Hagui, R. Essid, S. Amri, N. Feris, M. Khabbouchi, O. Tabbene, F. Limam, E. Srasra and N. Besbes, Turk. J. Chem. 43, 435-451. (2019)

7. N. Besbes, H. Jellala, M. L. Efrit and E. Srasra, J. Soc. Alger. Chim. 20(1), 61-71. (2010)

8. N. Besbes, D. Hadji, A. Mostfai, A. Rahmouni, M. L. Efrit and E. Srasra, J. Soc. Tun. 14, 39-46. (2012)

9. F. Steppeler, D. Kłopotowska, J. Wietrzyk, E. Wojaczy 'nska, Materials, 14, 2039. (2012)

10 A. M. Amer, A. Deeb, W. I. El-Eraky, S. A. El Awdan and M. Sebaey, Egypt. J. Chem. 67-77. (2018)

11. P. S. Patil, S. L. Kasare, N. B. Haval, V. M. Khedkar, P. P. Dixitc, E. M. Rekha, D. Sriram, K. P. Haval, Bioorg. Med. Chem. Lett. 30(19), 127434. (2020)

12. S. Ranjbar, P. Shahvaran, N. Edraki, M. Khoshneviszadeh, M. Darroudi, Y. Sarrafi, M. Hamzehloueian and M. Khoshneviszadeh, Arch Pharm. 353e, 2000058. (2020)

13. S. Dastmard, M. Mamaghani and M. Rassa, J. Chin. Chem. 67(8), 1437-1455. (2020) 
14. J. H. Mohammed and S. A. Aowda, Eur. J. Mol. Clin. Med. 07(08), 688-704. (2020)

15. Aziz-ur-Rehman, Y. Masih, M. A. Abbasi, S. Z. Siddiqui,T. Hussain and S. Rasool, Pak. J. Chem. 6(1-2), 10-15. (2016)

16. H. Elamari, I. Jlalia, C. Louet, J. Herscovici, F. Meganem and C. Girard, Tetrahedron- Asymmetry, 21(9-10), 11791183. (2010)

17. I. Jlalia, H. Elamari, F. Meganem, J. Herscovici, C. Girard, Tetrahedron Lett. 49(48), 6756-6758. (2008)

18. S. Neumann, M. Biewend, S. Rana and W. H. Binder, Macromol. Rapid Commun. 41, 1900359. (2020)

19. C. Girard, E. Önen, M. Aufort, S. Beauvière, E. Samson and J. Herscovici, Org. Lett. 8(8), 1689-1692. (2006)

20. R. Slimi, S. Kalhor-Monfared, B. Plancq and C. Girard, Tetrahedron Lett. 56(29), 4339-4344. (2015)

21. A. S. Stålsmeden, A. J. Paterson, I. C. Szigyártó, L. Thunberg, J. R. Johansson, T. Beke-Somfai, N. Kann, Org. Biomol. Chem. 18, 1957-1967. (2020)

22. P. Sudeep, C. B. Vagish, A. D. Kumar and K. A. Kumar, J. A. Chem. 13(8), 22-40. (2020)

23. T. Hossiennejad, M. Daraie, M. M. Heravi and N. N. Tajoddin, J. Inorg. Organomet Polym. 27, 861-870. (2017)

24. K. D. Khalil, S. M. Riyadh, S. M. Gomha and I. Ali, International Journal of Biological Macromolecules, 130, 928937. (2019)

25. I. Jlalia, F. Meganem, J. Herscovici and C. Girard, Molecules, 14(1), 528-539. (2009)

26. N. Hooper, L. J. Beeching, J. M. Dyke, A. Morris, J. S. Ogden, A. A. Dias, M. L. Costa, M. T. Barros, M. H. Cabrell and A. M. C. Moutinho, J. Phys. Chem. A. 106(42), 9968-9975. (2002)

27. L. Wang and C. Cai, Green Chem. Lett. Rev. 3(2), 121-125. (2019)

28. H. Elamari, F. Meganem, J. Herscovici and C. Girard, Tetrahedron Lett. 52(6), 658-660. (2011)

29. A. Ouerghui, H. Elamari, S. Ghammouri, R. Slimi, F. Meganem and C. Girard, React. Funct. Polym. 74, 37-45. (2014)

30. K. Prabakaran, S. Loganathan, M. S. Perumal and S. P. Anthony, Chemistry Select. 5, 8773-8778. (2020) 